\title{
1. Food security issues and the role of the multilateral trading system
}

Evan Rogerson and Diwakar Dixit*

\section{BACKGROUND}

Addressing food insecurity and malnutrition is one of the most pressing challenges that the global community faces. The Global Strategic Framework $^{1}$ adopted by the Committee on World Food Security has outlined some of the structural and underlying causes of food insecurity and malnutrition which, inter alia, include broader 'governance' issues, 'economic and production issues', 'demographic and social issues' and issues related to 'climate and environment'. A holistic consideration of this complex matrix of issues is needed. This is the approach taken by the UN High Level Task Force ${ }^{2}$ on Food Security in its comprehensive framework of action (UCFA).

While both demand and supply side factors were responsible for triggering the 2008 food crisis, overall food supply or availability has not presented a threat to global food security. Global food production/supply has consistently kept pace with demand that has been rising as a result of population and income increases. That is why Amartya Sen considered that food access (rather than availability) matters most: 'Starvation is the characteristic of some people not having enough food to eat. It is not the characteristic of there being not enough food to eat.'

This should not, however, belittle the scale of the challenge to increase global food production posed by the rising food demand that in turn results from growth in world population and income. According to FAO

\footnotetext{
* The views expressed in this chapter are solely the authors' responsibility and do not purport to be an official position of the WTO.

1 Accessible at: http://www.fao.org/cfs/cfs-home/global-strategic-framework/en/.

2 Since 2008, a UN Secretary General-led High-Level Task Force (UN HLTF) has been in action involving $23 \mathrm{UN}$ agencies and international organizations (including the WTO) towards an enhanced coordination and an effective food security response.

3 Amartya Sen, Poverty and Famines: An Essay on Entitlement and Deprivation (Clarendon Press 1981).
} 
estimates, world population is expected to reach more than nine billion by 2050 and feeding that population would necessitate raising overall food production by more than 60 per cent between $2005 / 07$ and $2050 .{ }^{4}$ This is seen as achievable subject to, inter alia, strengthened efforts towards increasing agricultural productivity and investment, more favourable domestic agricultural policy frameworks, enhanced global policy cooperation and free and functioning food markets. This chapter will focus on the role of trade and the multilateral trade framework of the WTO towards contributing to the food security objectives.

\section{THE MULTILATERAL TRADING SYSTEM AND FOOD SECURITY}

The majority of hungry and food insecure people in the world are directly or indirectly dependent on the agriculture sector for their livelihood and for improving their food security status. Governments principally focus on their agricultural policies in achieving national food security goals. The examination of the multilateral trade rules in this chapter will naturally focus on such rules as applicable to agricultural trade.

There is significant potential for enhancing agricultural production and productivity in many parts of the world. Countries should strive to harness this potential, which would significantly contribute to meeting food security goals. At times, the objective of augmenting agricultural productivity is stretched to make it appear equivalent to the attainment of food self-sufficiency. The notion of food self-sufficiency is often attractive from a political perspective; but the realization of such an objective would necessitate self-sufficiency in natural endowments (land, water, etc.) and supportive climatic conditions in order to produce everything that is demanded by consumers in a country. Natural resources are, however, not evenly distributed and neither are they proportionally aligned to the demographic situation of individual countries.

For almost all countries, national food self-sufficiency would be impractical, environmentally unsustainable and excessively costly. ${ }^{5}$ As the Director-General of the FAO has noted, in a globalized world, it is not

\footnotetext{
${ }^{4}$ This implies an additional annual consumption of 940 million tons of cereal and 200 million tons of meat by 2050 .

${ }^{5}$ Some activists even go further and advocate the so-called 'food sovereignty'. This notion conveys, inter alia, a sense that States must be allowed to intervene towards achieving food security goals even if those interventions conflict with their international commitments.
} 
possible to achieve food security in only one country. ${ }^{6}$ The notion of food self-sufficiency gained ground during the 2008 food crisis when many importing countries found themselves precariously exposed to an extreme price volatility originating in the international food market. Food selfsufficiency was then argued so as to insulate the domestic market and domestic consumers from highly volatile international food prices. These insular tendencies in turn expose the concerned countries to domestic food price volatility resulting from the local supply shocks that have recently become more frequent due, inter alia, to climatic aberrations.

Trade is an essential component of any food security strategy and acts as an engine to the transfer of products from surplus to deficit areas. The WTO system can contribute to global food security through reduction or elimination of trade-distorting measures and by providing a binding and predictable framework to guide intervention by governments in their agriculture sectors. The international commitments that governments have negotiated under the WTO help, not hinder, their achievement of food security goals. There are four specific aspects related to the multilateral trading system that should be highlighted in the context of the food security debate.

\section{(i) Reducing Trade Barriers Towards Open and Functioning Food Markets}

One of the most fundamental ways in which the WTO could contribute to global food security is through open, non-distorting and efficient agricultural trade. International trade offers an opportunity for income growth through improved access to external markets, thereby encouraging expansion of agricultural production. By way of encouraging competitiveness, international trade also assists in an efficient allocation of resources, thereby improving agricultural productivity. Food insecurity resulting from inhibited access to food is generally caused by a lack of income, and international trade through its income-enhancing potential could be an effective tool to enhance food access.

International trade also plays a balancing role by evening out supply fluctuations across the globe and thus containing food market price volatility. With climatic variations becoming more frequent and significant, resulting in frequent production shortfalls, the balancing and stabilizing role of trade will become increasingly important over time. Another factor which often aggravates pricing volatility is the fact that food markets

\footnotetext{
${ }^{6}$ See, by way of example, the statement made by the Director General on the occasion of World Food Day 2012 available at: http://www.fao.org/news/story/en/item/162391/ icode/.
} 
are 'thin' (i.e. a small share of production is traded internationally). The agricultural reform process that was launched in 1995 under the Uruguay Round Agreement on Agriculture ${ }^{7}$ (AoA) and being furthered through the Doha Round (DDA) agriculture negotiations would lead to 'fuller' food markets, thus dampening the global price volatility risks.

\section{Import barriers}

Tariff reductions under the WTO framework are pursued through commitments on tariff bindings. This contributes to open and predictable international food markets, increased trade volumes, and the ability to diversify sources of supply for food imports, and thus to enhanced food availability. Trade liberalization of agricultural products began after the entry into force of the AoA in 1995, which allows the use of tariffs for domestic producers against agricultural imports, but prohibits the application of agriculture-specific non-tariff border measures.

The existing agricultural tariff levels that WTO Members committed to after the conclusion of the Uruguay Round continue to be high. Achieving a substantial reduction of the existing tariff commitments, particularly high tariffs, is one of the important objectives of the DDA negotiations. In that endeavour, special attention is also paid to achieving enhanced market access for products that are of increasing export interest to developing countries. This effort would enable a greater contribution by the agriculture sector to income generation and food security outcomes in developing countries.

One developmental aspect that is often raised in the context of discussions regarding the contribution of the agriculture sector in developing countries is the level of enhanced value addition or product transformation that these countries should achieve domestically. A trade policy aspect that also invariably informs that discussion is tariffs on processed agricultural products and the escalation of those tariffs with increasing value addition. In the DDA agriculture negotiations, there is an emphasis on addressing this tariff escalation especially where it affects developing countries' exports.

\section{Export barriers}

During the 2008 food crisis, there was criticism that WTO rules do not discipline agricultural export restrictions. ${ }^{8}$ At the peak of the crisis, a number of countries were found to be adopting various measures limiting

\footnotetext{
7 Agreement on Agriculture (15 April 1994) LT/UR/A-1A/2.

8 The asymmetry in WTO rules on exports and imports become acute and more exposed when one considers tariff commitments on imports and exports, i.e. extensive tariff
} 
exports in order to retain their domestic production locally. Such restrictions raised concerns as to the reliability of the international market as a source of food supplies. ${ }^{9}$

While it is true that the import side is highly disciplined under the WTO rules in order to contain protectionism, the prohibition on maintaining quantitative restrictions (QRs) under GATT Article XI applies to both imports and exports. Members are therefore not generally permitted to maintain export quotas and bans on foodstuffs. Article XI:2(a) of GATT 1994 permits Members to temporarily restrict or prohibit exports of foodstuffs in order to prevent or relieve critical shortage of those foodstuffs. This provision allows Members to apply these, otherwise prohibited, measures temporarily to address critical situations concerning their food security.

Article 12 of the AoA attempts to balance the equation by addressing the concerns of importing Members whose food security may equally be threatened by such measures. Members instituting an export prohibition or restriction on foodstuffs shall give due consideration to the effects of such measures on importing Members' food security. To this end, the Members, before instituting such export limiting measures, shall make a notification to the Committee on Agriculture presenting the details of the measure including its proposed duration, and shall consult, upon request, with interested importing Members. ${ }^{10}$

Timely notifications in the area of export prohibitions and restrictions are seen as very important. These notifications not only ensure a proper review of such measures (i.e. to see that prescribed rules are followed) but they also provide a concrete opportunity to importing Members to seek consultations with the notifying Member in order to address their potential food security concerns. There has been an active discussion in the WTO Committee on Agriculture ( $\mathrm{CoA}$ ) aimed at improving the application of the existing rules. Additionally, in the DDA agriculture negotiations, rules on agricultural export restrictions are a part of the negotiating dossier and there are various negotiating proposals on the table on that issue.

bindings on imports and virtually non-existing export tariff bindings (except for some recently acceded Members).

9 One of the policy advisory proposed by a number of global collaborations on food security activated during the 2008 food crisis was to minimize the use of export restrictions on foodstuffs. The UN HLTF in its Framework, for example, recommended that governments 'ensure that local purchases of food and food components for humanitarian purposes are exempt from restrictions'. A similar declaration was agreed within the G20 framework.

${ }^{10}$ Developing country Members are exempted from these additional conditions prescribed in the AoA unless the developing country Member concerned is a net-exporter of the specific foodstuff concerned. 


\section{(ii) Multilateral Rules on Agricultural Subsidization}

Trade-distorting subsidy interventions in the agriculture sector by governments have for many years contributed to distorting international food markets and depressing agricultural production in poorer developing countries. These countries, despite their competitive advantage in the sector, faced adverse terms of trade for many decades in the post-war period. Such a negative scenario was also deemed responsible for contributing to under-investment in the agriculture sector and delayed agriculture policy reforms in a number of developing countries.

\section{Domestic subsidization}

One of the fundamental changes introduced by the multilateral agriculture rules negotiated in the Uruguay Round was the conclusion of binding rules on domestic agricultural subsidization. The aim is to ensure that the location and quantum of agricultural production is determined by competitive advantage rather than by the magnitude of financial interventions by governments. The rules under the 'domestic support' pillar of the AoA limit trade-distorting support by governments through the so-called reduction commitments and simultaneously leave ample scope for governments (and especially developing country governments) to design domestic agricultural policies in response to the specific circumstances of their agricultural sectors. For example, policies to create rural infrastructure, enhanced investment towards agricultural research, provision of training and extension services to farmers, etc., are explicitly encouraged under the Green Box ${ }^{11}$ by exempting them from any ceiling on support expenditures.

The multilateral framework on agricultural subsidization has helped to create a more enabling global policy environment to carry out much needed agricultural reforms and thus also contribute to food security objectives. However, trade distorting subsidy amounts that Members (and especially developed country Members) can spend under the existing commitments are still high. This is one of the important issues in the DDA agriculture negotiations that Members seek to address by means of a successful DDA outcome.

\section{Export subsidization}

Export subsidies are deemed as highly distorting in terms of their negative spillover effect as subsidization is targeted at production for export to the

11 Annex 2 of the AoA sets out the basic and policy-specific implementation criteria, which, if followed, allow the relevant domestic support measures to be placed in the Green Box. The support measures covered under the Green Box are not subject to any financial limitation under the WTO (i.e. exempt from reduction commitments). 
international market. Export subsidies on industrial goods have been prohibited under the GATT rules whereas in the case of agricultural primary products they remained permissible subject to a limited multilateral discipline. The proliferation of such subsidies was one of the reasons for disarray in the international food markets in the years prior to the launch of the Uruguay Round negotiations. These subsidies were also deemed responsible for a long-term depression in world prices of subsidized agri-food products, a phenomenon that acted as a deterrent to agricultural investment in many developing countries and prevented them from exploiting the full developmental potential of the agriculture sector.

The rules with regard to export subsidies agreed under the AoA prohibited the introduction of new export subsidies and reduced existing export subsidies. In the Doha negotiations, WTO Members, especially the developing country Members, demanded an end to export subsidies due to their negative effect on world prices and thus on domestic production and exports. In 2005, WTO Members agreed to the final objective of eliminating all types of export subsidies in the agriculture sector. At the 2013 Bali ministerial meeting, Members reaffirmed the importance of reaching this final objective as soon as possible.

One of the areas of focus of the DDA agriculture negotiations under the export competition pillar ensures that WTO Members do not circumvent their export subsidy commitments through the operation of agricultural exporting State trading enterprises (STEs). To this end, one of the decisions foreseen under the negotiations is the elimination of the use of export monopoly powers of exporting STEs. However, the food security aspect informs this negotiating discussion as it is proposed that agricultural exporting State trading enterprises in developing country Members be permitted to use or maintain their export monopoly powers in cases where such STEs aim to preserve domestic consumer price stability and to ensure food security.

\section{(iii) Issues Related to Net Food-importing Developing Countries}

At the time of the adoption of the Uruguay Round agricultural reform programme under the AoA, the Uruguay Round package also included a Decision concerning the possible negative effects of the reform programme on least-developed and net-food importing developing countries (NFIDCs). The decision fully recognizes the positive effect of the Uruguay Round outcome as a whole to the benefit of all WTO Members. Simultaneously, there is an acknowledgement that in pursuing liberalization of agricultural trade under to the Uruguay Round reform programme, least-developed and NFIDCs might face difficulties accessing food from the international market at reasonable terms and conditions. 
The underlying assumption was that the reform process may result in an upward move in those international food prices that remained depressed due to distorting subsidies in place prior to the launch of the reform programme. Those price movements might entail temporary adjustment costs for such food-importing developing countries.

In order to minimize the potential negative impact of the reform process, the Marrakesh Decision includes a number of mechanisms to ensure that the reform process does not adversely affect the availability of food aid at a level that would enable developing countries to meet their food needs. The CoA is mandated to monitor the Decision's follow-up. The CoA has established a WTO list of NFIDCs and carries out an annual monitoring of the follow-up to the Decision in its November sessions. The relevant international organizations are also invited to contribute to the annual monitoring exercise. The review of the levels of food aid established under the Food Aid Convention ${ }^{12}$ and the level of concessions of food aid are specifically considered during the CoA's annual monitoring exercise.

International food aid is also one of the issues considered in the DDA agriculture negotiations under the export competition pillar. The fundamental thrust of WTO negotiations on this topic is to ensure that the WTO Members do not use food aid operations to circumvent their export subsidy commitments and cause market displacement. Simultaneously, there is a recognition of the interest of food aid recipients in the negotiations: that the WTO disciplines to be agreed in the negotiations should not unintentionally impede the delivery of food aid provided to deal with emergency situations.

The AoA ${ }^{13}$ contains an undertaking on the part of WTO Members to work toward the development of multilateral disciplines on export credits and similar measures in recognition of the fact that such export financing measures could be used to circumvent export subsidy commitments. This task is now pursued as a part of the DDA agriculture negotiations. The Marrakesh Decision looks at the development of such multilateral disciplines on export credits and similar measures from an 'access to food' perspective and provides that the disciplines relating to such measures make appropriate provisions for differential treatment in favour of least-

\footnotetext{
12 The Food Aid Convention was a multilateral cooperation instrument that remained in operation from 1967 to 2012. Its aim was to contribute to world food security and to improve the ability of the international community to respond to emergency food situations and the food needs of developing countries. The Food Aid Convention has been succeeded by the Food Assistance Convention, which entered into force on 1 January 2013.

13 Article 10.2 of the AoA.
} 
developed and net food-importing developing countries. This aspect relating to net food importing countries contemplated in the Decision has been fully taken on board in the DDA agriculture negotiations.

\section{(iv) Multilateral Rules on Food Safety}

Food safety is intricately linked to food security. First, and most directly, safety and quality of food is critical from a nutritional perspective. Additionally, countries with proper food safety infrastructures in place can produce food that will have greater market demand and market access, and will thus be able to enhance their agricultural production and productivity. This in turn contributes to food security objectives. Food that is not safe cannot normally be consumed or traded and will thus potentially be wasted. Concerns related to food safety are one of the important reasons for food wastage at 'consumption' stage. In the food security debate, ${ }^{14}$ there is an enhanced focus on containing food losses and food waste towards augmenting the global availability of food.

The WTO has a rich set of rules in the areas of food safety and quality. WTO rules encourage a science-based approach and recourse to international standards for harmonization purposes. These rules are included under the two separate agreements on sanitary and phyto-sanitary issues (SPS) and technical barriers to trade (TBT). These agreements contain binding rules aimed at ensuring safety and quality of traded food and simultaneously preventing the use of these standards or measures in a discriminatory manner or for protectionist purposes. The WTO also houses and administers the Standards and Trade Development Facility (STDF), a global partnership that supports developing countries in building their capacity to implement international SPS standards and ability to gain or maintain access to markets.

\section{MINISTERIAL MEETING AT BALI}

On 3-7 December 2013, the WTO held its Ninth Ministerial Conference in Bali, Indonesia. Ministers adopted a series of decisions aimed at strengthening the effectiveness of the multilateral trading system. Specific mention is made of three decisions strongly linked to food security.

14 Zero food loss/waste is one of the five themes identified in the UN SG's Zero Hunger Challenge (ZHC). 


\section{(i) Decision on Public Stockholding for Food Security Purposes}

One of the most politically visible issues that the Bali ministerial meeting considered, based on a proposal by the G-33 group of developing countries, concerned developing country programmes on public stockholding for food security purposes. The existing WTO AoA rules under the Green Box ${ }^{15}$ permit governments to incur expenditures in relation to accumulation and holding of food stocks without any monetary limitation, provided the acquisition and the release of stocks is carried out under market conditions.

The specific issue under consideration at the Bali meeting concerned situations where public stockholding programmes in developing countries intersect with market price support (MPS) policies during the acquisition stage of stockholding. In such cases, under the existing AoA rules the developing country Members might still exempt their public stockholding programmes under the Green Box, provided the price support component is accounted for in the aggregate measurement of support (AMS) calculations. Considering the trade-distorting potential of market price support ${ }^{16}$ programmes, the existing rules on AMS calculations provide for a specific methodology to quantify such support. Some developing countries argued that the annual AMS amount calculated as per the prescribed methodology for their public stockholding programmes would lead them to breach their domestic support commitment.

As per the decision ${ }^{17}$ agreed at the Bali meeting, the developing country Members were granted interim protection against legal challenge under the AoA with regard to their existing public stockholding programmes in cases where support provided to traditional staple food crops in pursuance of such stockholding programmes conflict with AoA commitments. ${ }^{18}$ The beneficiary developing country Members will be subject to transparency, monitoring and consultation requirements. The Bali decision also provides that a fuller discussion on this topic will take place in the framework of a work programme on food security, to be conducted over the next four years, with the objective of finding a lasting solution. Later in November 2014, the General Council of the WTO adopted a decision ${ }^{19}$ clarifying that

\footnotetext{
15 Paragraph 3 of Annex 2 refers.

${ }^{16}$ In the lead-up to the Uruguay Round negotiations which finally created the rules on domestic subsidization under the AoA, market price support was the most prevalent category of trade-distorting support, often practiced by developed countries, and that was deemed responsible for the then existing disarray in agriculture markets.

17 WT/L/913 accessible at: http://wto.org/english/thewto_e/minist_e/mc9_e/desci38_e.htm.

18 Articles 6.3 and 7.2(b) of AoA refer.

$19 \mathrm{WT} / \mathrm{L} / 939$ refers.
} 
the interim mechanism will continue to be in place if a permanent solution were not to be agreed and adopted within the originally conceived fouryear time-frame and simultaneously agreed to make all concerted efforts to negotiate a permanent solution in a dedicated negotiating track by 31 December 2015.

\section{(ii) Decision on General Services}

One of the issues considered in the DDA agriculture negotiations has been towards encouraging an increasing recourse to Green Box programmes by developing countries. In this context, and recognizing the contribution that General Services programmes of the Green Box can make to rural development, food security and poverty alleviation, particularly in developing countries, the Ministers at Bali agreed ${ }^{20}$ to expand the illustrative list of General Services programmes to include various policies that are grounded on rural livelihood security and poverty alleviation objectives.

\section{(iii) Agreement on Trade Facilitation}

Specific mention should be made of the agreement ${ }^{21}$ that the WTO members adopted at Bali on Trade Facilitation (TF) towards expediting the movement, release and clearance of goods, including goods in transit. It is widely expected that the new trade facilitation agreement will reduce the transaction cost of trade through streamlined customs procedures, and will improve the predictability and transparency of market access opportunities in global markets, including food markets.

From a food security perspective, special mention may be made of provisions in the TF Agreement dealing with a speedy release of perishable goods. These rules will contribute to limiting food wastage especially in respect of perishable food products (such as fruits and vegetables) and thus contribute to food security through enhanced food availability.

${ }^{20}$ WT/L/912 accessible at http://wto.org/english/thewto_e/minist_e/mc9_e/desci37_e.htm.

${ }^{21} \mathrm{WT} / \mathrm{L} / 911$ accessible at http://wto.org/english/thewto_e/minist_e/mc9_e/desci36_e.htm. Later, in November 2014, the General Council adopted the Protocol (WT/L/940) amending the WTO Agreement so as to legally include the Agreement on Trade Facilitation among the multilateral agreements on trade in under Annex 1A of the WTO Agreement. 


\section{CONCLUSION}

Ensuring food security is primarily a national responsibility, but it is increasingly becoming a shared endeavour. National governments implement the policies they deem necessary to ensure food security for their people, but they are expected to pay due attention to their international obligations. In the area of agriculture, government policy behaviour was subject to a minimal set of multilateral trade obligations until the conclusion of the Uruguay Round and entry into force of the AoA. The agreed multilateral trade rules and disciplines under the AoA are good examples of how international cooperation can address issues that may not be effectively handled at the national level. Food security is a key case in point. These rules are an outcome of the decision by sovereign States to exercise their sovereignty in a more effective manner, which provides the greatest scope for effecting food security outcomes both nationally and globally.

The wide range of factors influencing food security means that the international effort must be similarly inclusive. No one agency or policy set has all the answers. As discussed above, trade policies and multilateral disciplines have an important contribution to make, but this will be more effective if is part of a coherent and mutually supportive approach shared by all the relevant actors.

The 2008 food crisis led governments and the international community to devote more attention to food and agricultural systems and especially to look deeper into the root causes of such a crisis. Serious remedial efforts to address agricultural under-investment, implement social safety-net programmes and address agricultural productivity, are but a few important manifestations of such endeavours by national governments and intergovernmental organizations. Simultaneously, the topic of agriculture and food systems has attracted global attention, as evidenced by numerous on-going international collaborations. Cooperative undertakings such as the UN High Level Task Force on Food Security and the Agricultural Markets Information System are making a difference to the overall governance food security, both in terms of early warning systems and of coherent messaging and action.

The WTO's participation in various food security discussions has been and continues to be an active one, outlining, inter alia, the important contributory role of the multilateral trading system towards achieving agricultural development and food security goals. The objective of our participation is to facilitate an informed consideration of the contribution trade and trade rules make to food security and to enhance that contribution by working with other agencies and with national governments to improve global responsiveness to food security challenges. 